\title{
The Role of Internet Development on Energy Intensity in China: Evidence From a Spatial Econometric Analysis
}

\author{
Yu Hao ${ }^{1}$, Haitao $\mathrm{Wu}^{2}$ a \\ ${ }^{1}$ Beijing Institute of Technology, China, ${ }^{2}$ Beijing institute of Technology, China \\ Keywords: spatial spillover, energy intensity, internet developmen \\ https://doi.org/10.46557/001c.17194
}

\section{Asian Economics Letters}

Vol. 1, Issue 1, 2020

With the emergence of information communication technology, the role of internet development has become crucial for energy intensity. This study uses the spatial Durbin model to test the impact of internet development on China's energy intensity. The results show that internet development reduces energy intensity. Internet development though carries spatial spillover effects, promoting energy intensity in adjacent areas.

\section{Introduction}

In this paper, we examine how the development of internet has impacted energy intensity in China. Our hypothesis is that internet development reduces energy intensity. The proposed relationship between internet development and energy intensity is motivated by the theory of information communication technology (ICT) and electricity consumption (EC) proposed by Cho et al. (2007). The ICT-EC theory argues that there is a significant negative relationship between ICT and EC. This theory predicts that internet development will have a positive effect on energy intensity. The hypothesis test we propose is important because China needs to find new ways to solve the dilemma of energy constraints in the era of digital economy (Wu et al., 2019).

To test our proposed hypothesis, we employ Chinese provincial level data covering the 2006-2017 period and find that internet development effectively promotes the decline in energy intensity. These findings make two contributions to the literature. The first is that this paper shows that the development of internet can reduce energy intensity, which further complements the theory of ICT and energy consumption. In fact, there is no literature on how the internet development affects the energy intensity. Our study fills this gap. The second is that the spatial spillover effect of internet development on energy intensity is investigated; this is one aspect of the literature not explored previously.

\section{Data and Methodology}

\section{A. Methodology}

\section{Spatial econometric model}

The theoretical framework for this study rests upon the highly popular conceptual framework, namely the Stochastic Impacts by Regression on Population, Affluence, and Technology (STIRPAT) model (Rafiq et al., 2016). The model can be specified as follows:

$$
E=F(P, A, T, Z)
$$

Where, $E$ is energy intensity; $P$ represents population; $A$ in- dicates affluence; $T$ is technological progress; and $Z$ indicates other factors affecting energy intensity, such as science and technology. Based on the theory of ICT and EC proposed by Cho et al. (2007), the STIRPAT model is extended in this paper. In other words, internet development is added to model (1) as part of other variables that affect energy intensity. In addition, according to Hao et al. (2020), energy consumption is spatially dependent; therefore, we use a spatial econometric model to estimate the relationship between internet development and energy consumption. Model (1) is further transformed into the following empirical model:

$$
\begin{array}{r}
e c i_{i t}=\alpha_{0}+\alpha_{1} \text { internet }_{\mathrm{it}}+\alpha_{2} \text { pop }_{\mathrm{it}}+\alpha_{3} \text { pgdp }_{\mathrm{it}}+\alpha_{4} r d_{\mathrm{it}}+ \\
\alpha_{5} W * \text { internet }_{\mathrm{it}}+\alpha_{i}+\varepsilon_{\mathrm{it}}
\end{array}
$$

Where, eci represents energy intensity; internet $_{i t}$ is the internet development; pop $_{i t}$ represents population; $p g d p_{i t}$ indicates affluence; $r d_{i t}$ is technological progress; $W$ represents spatial spillover effect; the individual fixed effect is represented by $\alpha_{i}$; and $\varepsilon_{i t}$ is the random error term. The spatial Durbin model is used for the regression analysis in this paper.

\section{Spatial weight matrix}

In this paper, spatial weight matrix mainly includes the geographic distance weight matrix, $W_{1}$ and the economic weight matrix, $W_{2}$. In addition, in order to avoid possible measurement errors of the distance between the full samples, different thresholds are selected to set the local spatial weight matrix. This follows the study of Hao et al. (2020) and we set the thresholds as 400 kilometers, 600 kilometers, 800 kilometers, 1000 kilometer, 1500 kilometers and 2000 kilometers to investigate the impact of internet development on energy intensity in China.

\section{Spatial autocorrelation test}

In this paper, Moran's I index is used for spatial autocorrelation test. The calculation method of Moran's I index is shown in equation (3): 
Table 1: Evaluation system of internet development

\begin{tabular}{|c|c|c|c|c|}
\hline Target level & Standard level & Index level & Interpretation of indicators & Unit \\
\hline \multirow{10}{*}{$\begin{array}{c}\text { Internet } \\
\text { development }\end{array}$} & \multirow{3}{*}{$\begin{array}{c}\text { Internet } \\
\text { popularization }\end{array}$} & $\begin{array}{l}\text { Popularity rate of } \\
\text { internet users }\end{array}$ & $\begin{array}{c}\text { Reflecting the popularity of provincial } \\
\text { internet }\end{array}$ & $\%$ \\
\hline & & Number of internet users & $\begin{array}{l}\text { Measuring the demand capacity of } \\
\text { interprovincial internet services }\end{array}$ & $\begin{array}{l}10000 \\
\text { people }\end{array}$ \\
\hline & & Proportion of IPv4 & $\begin{array}{l}\text { Reflecting the fact of provincial IP address } \\
\text { resource allocation }\end{array}$ & $\%$ \\
\hline & \multirow{3}{*}{$\begin{array}{l}\text { Internet } \\
\text { infrastructure }\end{array}$} & $\begin{array}{l}\text { Number of domain } \\
\text { names }\end{array}$ & $\begin{array}{l}\text { Reflecting the configuration of provincial } \\
\text { domain name resources }\end{array}$ & $\begin{array}{l}\text { Unit/ } \\
10000 \\
\text { people }\end{array}$ \\
\hline & & $\begin{array}{l}\text { Length of long distance } \\
\text { optical fiber }\end{array}$ & $\begin{array}{l}\text { Reflecting the investment and construction } \\
\text { of provincial optical cable infrastructure }\end{array}$ & $\begin{array}{l}10000 \\
\text { kilometers }\end{array}$ \\
\hline & & $\begin{array}{l}\text { Number of internet } \\
\text { access ports }\end{array}$ & $\begin{array}{l}\text { Reflecting the construction level of } \\
\text { provincial internet access equipment }\end{array}$ & $\begin{array}{c}10000 \\
\text { unit }\end{array}$ \\
\hline & \multirow{2}{*}{$\begin{array}{l}\text { Internet } \\
\text { information } \\
\text { resources }\end{array}$} & $\begin{array}{l}\text { The average number of } \\
\text { bytes in a web page }\end{array}$ & $\begin{array}{l}\text { Reflecting the richness of provincial } \\
\text { internet information resources }\end{array}$ & $\mathrm{kb}$ \\
\hline & & $\begin{array}{l}\text { Average number of } \\
\text { websites owned by } \\
\text { enterprises }\end{array}$ & $\begin{array}{l}\text { Measuring the allocation level of } \\
\text { interprovincial internet Information } \\
\text { Resources }\end{array}$ & unit \\
\hline & \multirow[b]{2}{*}{$\begin{array}{l}\text { Internet } \\
\text { application }\end{array}$} & $\begin{array}{l}\text { Numbers of express } \\
\text { delivery }\end{array}$ & $\begin{array}{l}\text { Reflecting the development level of the } \\
\text { provincial online shopping industry }\end{array}$ & $\begin{array}{l}10000 \\
\text { unit }\end{array}$ \\
\hline & & $\begin{array}{l}\text { Total revenue of } \\
\text { telecommunication } \\
\text { business }\end{array}$ & $\begin{array}{l}\text { Reflecting the development of } \\
\text { telecommunication industry }\end{array}$ & $\begin{array}{l}\text { Billion } \\
\text { yuan }\end{array}$ \\
\hline
\end{tabular}

This table reports the evaluation criteria of internet development level. The first column is the target result, that is, the comprehensive level of internet development; the second column is the sub-indicators of internet development; the third column is the specific variable composition of the four sub-indicators; and the fourth column is the definition of specific variables. The last column is the unit of each variable.

$$
\text { Moran's I }=\sum_{\mathrm{i}=1}^{N} \sum_{\mathrm{j}=1}^{N} W_{\mathrm{ij}}\left(x_{i}-\overline{\mathrm{x}}\right)\left(x_{j}-\overline{\mathrm{x}}\right) / \mathrm{S}^{2} \sum_{\mathrm{i}=1}^{N} \sum_{\mathrm{j}=1}^{N} W_{\mathrm{ij}}
$$

In model (3), the energy intensity of province $i$ is represented as $x_{i}$, and $N$ represents the total number of geographic units (the provinces in this article), $\bar{x}$ represents the average value of energy intensity, and $S^{2}$ represents the variance of the energy intensity level. In addition, Moran's I can be statistically tested by the $Z$ value. The specific formula is:

$$
Z\left(\text { Moran's I) }=\frac{\text { Moran's I-E }(\text { Moran's I) }}{\sqrt{\text { VAR }(\text { Moran's I) }}}\right.
$$

where $E$ (Moran's I) $=-\frac{1}{n-1}$.

\section{B. Data}

According to previous studies, energy intensity is measured by energy consumption per unit of GDP (Chang et al., 2015; Wu et al., 2019). As for the internet development, most scholars use single indicators, such as internet penetration rate and the number of websites, to proxy the internet development level (Czernich et al., 2011; Koutroumpis, 2009). In fact, although the above single indicators are important indicators of the level of internet development, some indicators can only reflect the local facts of internet development and cannot objectively reveal the real level of internet development. Therefore, this paper constructs a measure of internet development level in China from four dimensions of internet popularization: namely, internet infrastructure, internet information resources, and internet application. We use the entropy method to calculate the comprehensive level of internet development in China. The evaluation system of China's internet development level is shown in Table 1.

In addition, we have several control variables, such as population, GDP per capita, and R\&D investment intensity, as proxies for population ( $p o p)$, wealth ( $p g d p)$ and technology ( $r d$ ), respectively (Hao et al., 2020; Wu et al., 2019). The GDP series has been converted to the constant 2006 price. In this paper, the panel data for 30 Chinese provinces are for the 2006-2017 period. Due to the lack of data, Hong Kong, Macao, Taiwan and Tibet regions with more missing values are excluded. Relevant data are from the China Statistical Yearbook, the China Internet Development Statistical report, the China Science and Technology Statistical Yearbook, and the China Energy Statistical Yearbook ${ }^{1}$.

\section{Empirical Results \\ A. Spatial correlation test}

A geographic distance weight matrix, economic weight matrix, and six local spatial weight matrices are used. Based on these eight weight matrices, the Moran's I energy intensity in 30 provinces in China for the 2006 to 2017 period is

1 For convenience, the term "province” is utilized to represent all provincial administrative units in China. 
Table 2: Moran's I of energy intensity concentration in 30 provinces of China from 2006 to 2017

\begin{tabular}{|c|c|c|c|c|c|c|c|c|c|}
\hline Year & Moran's & $W_{1}$ & $w_{2}$ & $W_{400 \mathrm{~km}}$ & $W_{600 \mathrm{~km}}$ & $W_{800 \mathrm{~km}}$ & $\mathrm{~W}_{1000 \mathrm{~km}}$ & $W_{1500 \mathrm{~km}}$ & $\mathrm{~W}_{2000 \mathrm{~km}}$ \\
\hline \multirow{2}{*}{2006} & Moran's & $0.279^{* * *}$ & $0.038^{* *}$ & $0.254^{*}$ & $0.207^{* *}$ & $0.181^{* *}$ & $0.171^{* * *}$ & $0.146^{* * *}$ & $0.099^{* * *}$ \\
\hline & & [2.710] & [2.276] & [1.573] & [1.813] & [1.956] & [2.475] & [3.024] & 2.991] \\
\hline \multirow[t]{2}{*}{2007} & $\begin{array}{c}\text { Moran's } \\
\text { I }\end{array}$ & $0.271^{* * *}$ & $0.039^{* *}$ & $0.290^{* *}$ & $0.206^{* *}$ & $0.177^{* *}$ & $0.164^{* * *}$ & $0.140^{* * *}$ & $0.096^{* * *}$ \\
\hline & & [2.587] & [2.252] & [1.734] & [1.776] & [1.879] & [2.352] & [2.864] & [2.867] \\
\hline \multirow{2}{*}{2008} & $\begin{array}{c}\text { Moran's } \\
\text { I }\end{array}$ & $0.238^{* *}$ & $0.037^{* *}$ & $0.305^{* *}$ & $0.191^{*}$ & $0.160^{* *}$ & $0.148^{* *}$ & $0.128^{* * *}$ & $0.087^{* * *}$ \\
\hline & & [2.280] & [2.170] & [1.795] & [1.646] & [1.709] & [2.134] & [2.654] & [2.653] \\
\hline \multirow[t]{2}{*}{2009} & $\begin{array}{c}\text { Moran's } \\
\text { I }\end{array}$ & $0.212^{* *}$ & $0.033^{* *}$ & $0.306^{* *}$ & $0.175^{*}$ & $0.145^{*}$ & $0.133^{* *}$ & $0.118^{* * *}$ & $0.079^{* * *}$ \\
\hline & & [2.063] & [0.033] & [1.801] & [1.526] & [1.576] & [1.952] & [2.480] & [2.477] \\
\hline \multirow{2}{*}{2010} & Moran's & $0.197^{* *}$ & $0.030^{* *}$ & $0.301^{* *}$ & $0.160^{*}$ & $0.135^{*}$ & $0.121^{* *}$ & $0.108^{* *}$ & $0.073^{* * *}$ \\
\hline & & [1.943] & [1.954] & [1.772] & [1.417] & [1.492] & [1.825] & [2.313] & [2.346] \\
\hline \multirow{2}{*}{2011} & $\begin{array}{c}\text { Moran's } \\
\text { I }\end{array}$ & $0.176^{* *}$ & $0.029^{* *}$ & $0.302^{* *}$ & $0.148^{*}$ & $0.129^{*}$ & $0.121^{* *}$ & $0.106^{* * *}$ & $0.074^{* * *}$ \\
\hline & & [1.755] & [1.946] & [1.778] & [1.329] & [1.435] & [1.821] & [2.286] & [2.358] \\
\hline \multirow{2}{*}{2012} & $\begin{array}{c}\text { Moran's } \\
\text { I }\end{array}$ & $0.168^{* *}$ & $0.034^{* *}$ & $0.313^{* *}$ & $0.153^{*}$ & $0.135^{*}$ & $0.133^{* *}$ & $0.118^{* * *}$ & $0.083^{* * *}$ \\
\hline & & [1.677] & [2.057] & [1.817] & [1.353] & [1.472] & [1.942] & [2.462] & [2.531] \\
\hline \multirow{2}{*}{2013} & Moran's & $0.176^{* *}$ & $0.035^{* *}$ & $0.309^{* *}$ & $0.154^{*}$ & $0.139^{*}$ & $0.138^{* *}$ & $0.130^{* * *}$ & $0.091^{* * *}$ \\
\hline & & [1.734] & [2.077] & [1.792] & [1.355] & [1.506] & [1.984] & [2.633] & [2.701] \\
\hline \multirow{2}{*}{2014} & Moran's & $0.171^{* *}$ & $0.042^{* *}$ & $0.328^{* *}$ & $0.177^{*}$ & $0.155^{*}$ & $0.155^{* *}$ & $0.148^{* * *}$ & $0.104^{* * *}$ \\
\hline & & [1.686] & [2.300] & [1.879] & [1.513] & [1.634] & [2.178] & [2.914] & [2.955] \\
\hline \multirow[t]{2}{*}{2015} & $\begin{array}{c}\text { Moran's } \\
\text { I }\end{array}$ & $0.181^{* *}$ & $0.043^{* *}$ & $0.338^{* *}$ & $0.176^{*}$ & $0.159^{* *}$ & $0.158^{* *}$ & $0.148^{* * *}$ & $0.105^{* * *}$ \\
\hline & & [1.768] & [2.308] & [1.927] & [1.505] & [1.663] & [2.206] & [2.897] & [2.981] \\
\hline \multirow[t]{2}{*}{2016} & $\begin{array}{c}\text { Moran's } \\
\text { I }\end{array}$ & $0.219^{* *}$ & $0.070^{* *}$ & $0.503^{* * *}$ & $0.253^{* *}$ & $0.217^{* *}$ & $0.201^{* * *}$ & $0.183^{* * *}$ & $0.133^{* * *}$ \\
\hline & & [2.073] & [3.121] & [2.783] & [2.048] & [2.162] & [2.694] & [3.462] & [3.575] \\
\hline \multirow{2}{*}{2017} & $\begin{array}{c}\text { Moran's } \\
\text { I }\end{array}$ & $0.176^{* *}$ & $0.052^{* *}$ & $0.401^{* *}$ & $0.198^{* *}$ & $0.171^{* *}$ & $0.164^{* *}$ & $0.150^{* * *}$ & $0.109^{* * *}$ \\
\hline & & [1.734] & [2.606] & [2.266] & [1.668] & [1.777] & [2.285] & [2.955] & [3.080] \\
\hline
\end{tabular}

This table reports the spatial correlation test of China's energy intensity from 2006 to $2017 . \mathrm{W}_{1}$ and $\mathrm{W}_{2}$ represent the basic geographic and economic weight matrices, respectively. $\mathrm{W}_{400 \mathrm{~km}}, \mathrm{~W}_{600 \mathrm{~km}}, \mathrm{~W}_{800 \mathrm{~km}}, \mathrm{~W}_{1000 \mathrm{~km}}, \mathrm{~W}_{1500 \mathrm{~km}}$ and $\mathrm{W}_{2000 \mathrm{~km}}$ represent the spatial weight matrix of six different distances; $\mathrm{Z}$ statistics are in parentheses; and * $\mathrm{p}<0.1$, *** $\mathrm{p}<0.05$, and ****\% $\mathrm{p}<0.01$.

calculated. The significance of the results is tested by using the $\mathrm{Z}$ distribution. The specific results are shown in Table 2. Columns 3 to 10 in Table 2 are "Moran's I" of the local weight matrix based on geographic distance weight matrix, economic weight matrix, and $400 \mathrm{~km}, 600 \mathrm{~km}, 800 \mathrm{~km}$, $1000 \mathrm{~km}, 1500 \mathrm{~km}$ and $2000 \mathrm{~km}$ thresholds. From Table 2, we see that during the 2006-2017 period, all “Moran's I" are significant at least at the $10 \%$ level of significance. Therefore, China's energy intensity is characterized by significant spatial dependence. In addition, most of China's provinces were located in the first and third quadrants in 2006 (see Figures 1), indicating that China's energy intensity has spatial correlation.

\section{B. Regression results of spatial econometric model}

In the previous section, we found that China's energy intensity has spatial correlation. This section studies the impact of internet development on energy intensity. According to Table 3 , under different types of spatial weight matrix, the coefficient of internet development is significantly negative. This result shows that internet development reduces energy intensity. Meanwhile, under the spatial weight matrix with different distances, the coefficients of internet development show that it rises first then falls as the spatial distance increases. Interestingly, from the perspective of spatial spillover effect ( $W^{*}$ internet), internet development 
Table 3: Internet development and energy intensity

\begin{tabular}{|c|c|c|c|c|c|c|c|c|}
\hline Variables & $W_{1}$ & $W_{2}$ & $\mathrm{~W}_{400 \mathrm{~km}}$ & $\mathrm{~W}_{600 \mathrm{~km}}$ & $\mathrm{~W}_{800 \mathrm{~km}}$ & $\mathrm{~W}_{1000 \mathrm{~km}}$ & $W_{1500 \mathrm{~km}}$ & $\mathrm{~W}_{2000 \mathrm{~km}}$ \\
\hline \multirow[t]{2}{*}{ internet } & $-1.962^{* * *}$ & $-1.612^{* * *}$ & $-1.733^{* *}$ & $-2.167^{* * *}$ & $-2.308^{* * *}$ & $-2.079^{* * *}$ & $-1.940^{* * *}$ & $-1.715^{* * *}$ \\
\hline & $(-3.136)$ & $(-2.868)$ & $(-2.393)$ & $(-3.017)$ & $(-3.473)$ & $(-3.188)$ & $(-3.194)$ & $(-2.992)$ \\
\hline \multirow[t]{2}{*}{ pop } & 1.170 & $2.534^{*}$ & 1.505 & 1.507 & 1.747 & 1.802 & 2.110 & 2.347 \\
\hline & $(0.717)$ & (1.718) & $(0.781)$ & $(0.774)$ & (0.986) & (1.050) & (1.311) & $(1.565)$ \\
\hline \multirow[t]{2}{*}{ pgdp } & $-0.048^{* * *}$ & $-0.036^{* * *}$ & $-0.082^{* * *}$ & $-0.079^{* * *}$ & $-0.062^{* * *}$ & $-0.055^{* * *}$ & $-0.044^{* * *}$ & $-0.036^{* * *}$ \\
\hline & $(-8.160)$ & $(-7.169)$ & $(-14.302)$ & $(-12.651)$ & $(-10.013)$ & $(-9.025)$ & $(-7.689)$ & $(-7.105)$ \\
\hline \multirow[t]{2}{*}{$r d$} & 0.089 & $0.315^{* * *}$ & -0.003 & 0.075 & 0.158 & $0.222^{* *}$ & $0.281^{* * *}$ & $0.288^{* * *}$ \\
\hline & $(0.874)$ & (3.417) & $(-0.029)$ & $(0.621)$ & (1.433) & $(2.066)$ & (2.783) & (3.079) \\
\hline \multirow[t]{2}{*}{$W^{*}$ internet } & $2.355^{* *}$ & $3.925^{* * *}$ & 2.128 & $3.636^{* * *}$ & $4.560^{* * *}$ & $3.814^{* * *}$ & $3.782^{* * *}$ & $3.242^{* * *}$ \\
\hline & $(2.145)$ & (3.043) & (1.623) & (3.022) & (3.866) & $(2.992)$ & (3.184) & $(2.652)$ \\
\hline Spatial rho & $(12.849)$ & $(22.416)$ & (6.323) & (5.558) & $(9.536)$ & $(11.347)$ & (15.369) & $(21.084)$ \\
\hline \multirow[t]{2}{*}{$\begin{array}{l}\text { Variance } \\
\text { sigma2_e }\end{array}$} & $0.080^{* * *}$ & $0.065^{* * *}$ & $0.108^{* * *}$ & $0.109^{* * *}$ & $0.092^{* * *}$ & $0.087^{* * *}$ & $0.077^{* * *}$ & $0.067^{* * *}$ \\
\hline & $(12.383)$ & $(12.603)$ & $(12.705)$ & $(12.708)$ & $(12.568)$ & $(12.596)$ & $(12.618)$ & $(12.591)$ \\
\hline$N$ & 330 & 330 & 330 & 330 & 330 & 330 & 330 & 330 \\
\hline
\end{tabular}

This table reports the results of the spatial regression under different spatial weight matrices. Spatial rho is the test result of spatial correlation; $W^{*}$ Internet is the multiplication of the spatial weight matrix and the core variable, Internet, as well as the spatial spillover effect. In addition, $t$-statistics are provided in parentheses. Finally, ${ }^{*} \mathrm{p}<0.1$, ${ }^{* *} \mathrm{p}<0.05$, and ****: $\mathrm{p}<0.01$.

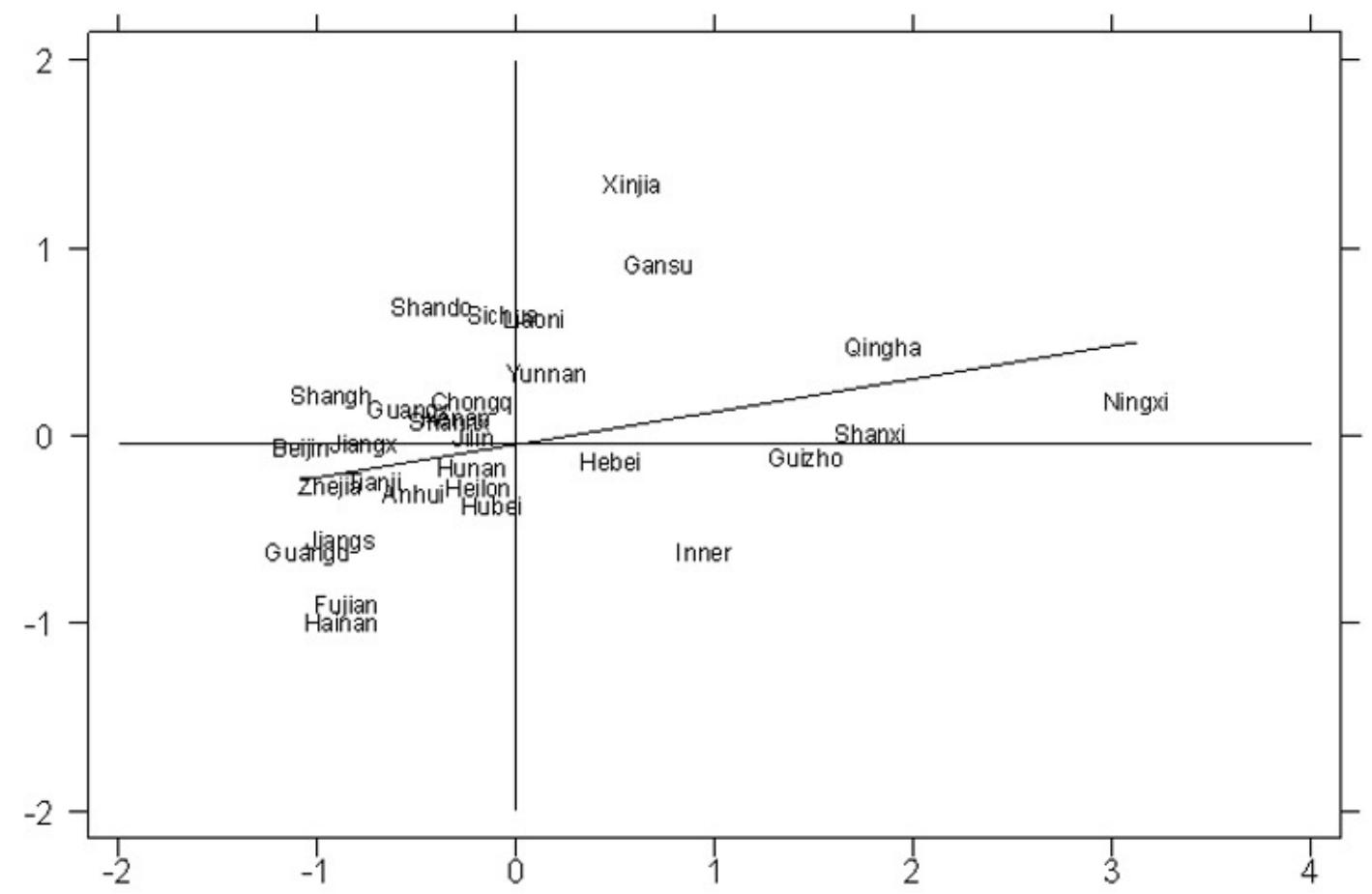

Figure 1: Scatter plot of the Moran index of China's energy intensity in $2006\left(\mathrm{~W}_{1}\right.$ as spatial weight matrix)

This figure reports results of the Moran index test. Moran index chart can directly show whether there is spatial correlation of China's energy intensity. The sample in the figure represents different provinces in China.

has promoted energy intensity of adjacent areas. The spatial spillover effect of internet is not significant only when the spatial weight matrix is $400 \mathrm{~km}$. In addition, from the regression results of the control variables, there is no significant correlation between population and energy intensity; the increase in per capita GDP reduces energy intensity; and the progress of science and technology promotes energy intensity, but it is only significant in economic weight matrix, W1000, W1500 and W2000. 


\section{Conclusion}

This paper studies how the development of the internet affects energy intensity by using the spatial Durbin model and China's inter-provincial panel data from 2006 to 2017. First, we use the entropy method to measure the level of internet development level in different Chinese provinces from the perspectives of internet popularization, internet infrastructure, internet information resources and internet application. Second, a variety of spatial weight matrices are constructed to test the relationship between internet development and China's energy intensity. The results show that the development of internet has generated a spatial spillover effect, which significantly reduces the energy intensity, but increases the energy intensity of the adjacent areas.

\section{Acknowledgment}

The authors acknowledge financial support from the National Natural Science Foundation of China (71761137001, 71403015, 71521002), the Beijing Natural Science Foundation (9162013), the key research program of the Beijing Social Science Foundation (17JDYJA009), the National Key Research and Development Program of China (2016YFA0602801, 2016YFA0602603), the Joint Development Program of the Beijing Municipal Commission of Education, and the silk road foundation of Xinjiang University (JGSL17021). The usual disclaimer applies.

Submitted: August 06, 2020 AEDT, Accepted: August 31, 2020

AEDT 


\section{REFERENCES}

Chang, C.-P., Lee, C.-C., \& Berdiev, A. N. (2015). The impact of government ideology on energy efficiency: Evidence from panel data. Energy Efficiency, 8(6), 1181-1199. https://doi.org/10.1007/s12053-015-934 $\underline{7-1}$

Cho, Y., Lee, J., \& Kim, T.-Y. (2007). The impact of ICT investment and energy price on industrial electricity demand: Dynamic growth model approach. Energy Policy, 35(9), 4730-4738. https://doi.org/10.1 016/j.enpol.2007.03.030

Czernich, N., Falck, O., Kretschmer, T., \& Woessmann, L. (2011). Broadband infrastructure and economic growth. The Economic Journal, 121(552), 505-532. https://doi.org/10.1111/i.1468-0297.2011.02 420.X

Hao, Y., Gai, Z., \& Wu, H. (2020). How do resource misallocation and government corruption affect green total factor energy efficiency? Evidence from China. Energy Policy, 143, 111562. https://doi.org/1 0.1016/j.enpol.2020.111562
Koutroumpis, P. (2009). The economic impact of broadband on growth: A simultaneous approach. Telecommunications Policy, 33(9), 471-485. https://d oi.org/10.1016/i.telpol.2009.07.004

Rafiq, S., Salim, R., \& Nielsen, I. (2016). Urbanization, openness, emissions, and energy intensity: A study of increasingly urbanized emerging economies. Energy Economics, 56, 20-28. https://doi.org/10.1016/j.enec 0.2016.02.007

Wu, H., Hao, Y., \& Weng, J.-H. (2019). How does energy consumption affect China's urbanization? New evidence from dynamic threshold panel models. Energy Policy, 127, 24-38. https://doi.org/10.1016/i.e npol.2018.11.057 